\title{
Didikan Allah Kepada Bangsa Israel Menurut Kitab Hakim-Hakim
}

\author{
Yosia Belo \\ Sekolah Tinggi Teologi Injili Arastamar (SETIA) Jakarta \\ ociebelo42@gmail.com
}

\begin{abstract}
The Book of Judges is a book that is paradoxical. Because in it there are several historical stories of the Israelites starting from the most famous and also the ones that are not well known. The book of Judges contains many interesting things, but also maybe a lot more disgusting things that the Israelites had done at that time, such as idolatry, adultery, civil war, mixed marriage, and so on. The teaching is simple, but difficult to understand, because in the book of Judges it shows the darkest sins of mankind, but in it the light of God's grace can be seen clearly. Based on the description above, teaching that comes from God is very necessary. It was useful to lead the Israelites on the right path or to bring the Israelites back to their God, who had freed them from slavery in Egypt and also gave them the land of Canaan as an inheritance. This article is an analysis and literature study, which describes some of the ways that God used to educate the Israelites who were corrupted by sin to become Israelites who obeyed God's Law.
\end{abstract}

Keywords: Allah's Education, Judges, Israel

Abstrak: Kitab Hakim-hakim adalah kitab yang bersifat paradoks. Oleh karena di dalamnya terdapat beberapa cerita sejarah bangsa Israel mulai dari yang paling terkenal serta yang juga yang tidak terkenal. Kitab Hakim-hakim mengandung banyak hal menarik, akan tetapi juga mungkin lebih banyak hal yang menjijikkan yang pernah dilakukan oleh bangsa Israel pada zaman itu, seperti penyembahan berhala, perzinahan, perang saudara, kawin campur, dan sebagainya. Pengajarannya sederhana, akan tetapi sulit untuk dimengerti, karena dalam kitab Hakim-hakim ${ }^{1}$ ini memperlihatkan dosa manusia yang paling hitam pekat, tetapi di dalamnya cahaya rahkmat Allah dapat dilihat dengan jelas. Berdasarkan uraian di atas, maka pengajaran yang bersumber dari pada Allah sangat diperlukan. Berguna untuk membawa bangsa Israel kepada jalan yang benar atau membawa kembali bangsa Israel kepada Allah mereka, yang telah membebaskan mereka dari perbudakan di Mesir serta juga memberikan tanah Kanaan kepada mereka sebagai milik pusaka. Artikel ini adalah sebuah analisis dan studi pustaka, yang memaparkan beberapa cara yang Allah gunakan untuk mendidik bangsa Israel yang telah rusak karena dosa menjadi bangsa Israel yang taat terhadap Taurat Tuhan.

Kata Kunci: Didikan Allah, Hakim-hakim, Bangsa Israel

\section{Pendahuluan}

Dalam Alkitab, diketahui bahwa ada berbagai cara Allah yang digunakan dan dilakukan-Nya untuk mendidik umat-Nya. Hal itu dilakukan Allah sebagai bagian dari rencana-Nya untuk menguduskan, membersihkan, menyelamatkan, dan menebus mereka, agar kehidupan mereka layak di hadapan Allah. Dalam kasus yang akan dijelaskan dalam artikel ini, penulis hendak mengaitkannya dengan Pendidikan Agama Kristen (PAK), dan diharapkan dapat diterapkan dalam mengajar peserta didik. Sebagaimana dipahami bahwa dalam PAK, memiliki tujuan bukan hanya menjadikan

${ }^{1}$ Kitab Hakim-hakim dalam kanon Ibrani tergolong ke dalam Kitab Nabi-nabi Terdahulu bersama dengan Kitab Yosua, Raja-raja (yang kemudian terbagi ke dalam 1 dan 2 Raja-raja, dan Kitab Samuel (yang kemudian terbagi ke dalam 1 dan 2 Samuel). Namun dalam Kanon Yunani (Kristen), Kitab Rut disisipkan di antara Hakim-hakim dan 1 Samuel. 


\section{Yosia Belo}

peserta didik pintar secara intelektual, akan tetapi yang lebih penting adalah membuat peserta didik memiliki moral yang baik, seturut dengan kehendak Tuhan.

\section{Metode Penelitian}

Pada penelitian ini, penulis atau peneliti menggunakan pendekatan atau metode kualitatif untuk memperoleh data yang valid guna membangun sebuah teori yang berkaitan dengan tema atau pokok penelitian. Metode kualitatif yang dimaksud adalah mengkaji dan mengelaborasi setiap sumber, informasi dan data-data yang diperoleh dari pustaka.

\section{Hasil dan Pembahasan}

\section{A. Allah Mendisiplin Saat Bangsa Israel Melakukan Kesalahan}

Yongky Karman dalam seminarnya tentang Kitab Hakim-Hakim menjelaskan, bahwa 'dalam kitab Hakim-hakim, Allah memberikan disiplin kepada bangsa Israel saat melakukan kesalahan, serta membebaskan umatnya dengan siklus dosa, seperti: pertobatan - pembebasan - berdosa kembali. $^{2}$ Siklus dosa orang Israel dalam zaman hakim-hakim, menurut Karman, adalah: "pertama, Israel melakukan apa yang jahat di mata Tuhan; kedua, Tuhan menyerahkan mereka ke dalam tangan penindasan; ketiga, Israel berseru kepada Tuhan; keempat, Tuhan membangkitkan seorang pembebas (hakim) bagi bangsa Israel; dan kelima, Tuhan menyerahkan penindasan itu kepada seorang penyelamat-penyelamat. ${ }^{3}$

Dari uraian di atas, tampak bahwa bangsa Israel yang tertindas kemudian berseru kepada Tuhan, dibebaskan oleh Tuhan dari penindasan dan perbudakan bangsa lain. Siklus dosa dalam zaman hakim-hakim seperti: pertobatan, pembebasan, lalu berdosa lagi; memperlihatkan kemerosotan moral yang sangat memprihatinkan dalam sejarah bangsa Israel. Hal ini terlihat dalam tiga bagian dari kitab Hakim-hakim tersebut, yakni:

Pertama, kemerosotan itu sudah diantisipasi dalam bagian pengantar $(1: 1 ; 3: 6)$, secara historis $(1: 1 ; 2: 5)$ maupun teologis $(2: 6 ; 3: 6)$. Dalam pengantar historis, riwayat sukses bangsa Israel keluar dari Mesir menuju tanah Kanaan (Tanah Perjanjian) diikuti juga dengan kegagalan mereka dalam perang. Hal ini dapat dilihat sebagai tanda tindakan disiplin yang bersumber dari Tuhan. Oleh karena dalam Perjanjian Lama sesuai dengan kovenan yang pernah diikat antara Allah dengan bangsa Israel, tindakan menyembah ilah-ilah lain selain YHWH (Allah orang Israel) sama saja dengan melanggar dan meninggalkan perjanjian tersebut. M. P. Aritonang dalam diktat "Pengantar dan Pembimbing Perjanjian Lama" juga menjelaskan, bahwa "penindasan sebagai sarana yang Allah pakai untuk mendisiplinkan umat-Nya serta menuntut pertobatan dan permohonan ampun dari bangsa Israel melalui hakim-hakim yang telah ditentukan Allah untuk menyelamatkan umat-Nya". ${ }^{4}$

Berdasarkan pandangan di atas maka dapat dijelaskan bahwa melalui para hakim, Tuhan bermaksud mengingatkan kembali bangsa Israel akan providensia Allah bagi mereka yang tidak pernah terputus sejak exodus dari Mesir sampai berhasil merebut Tanah Kanaan dan memilikinya. Selain itu, Tuhan juga bermaksud untuk mendisiplinkan mereka supaya mereka sadar dan kembali berpaling kepada Allah. Apabila melihat tujuan dari kehadiran para hakim, bukan saja untuk menjadi panglima perang atau

\footnotetext{
2 Yongky Karman, "Seminar Kitab Hakim-hakim”.

3 Yonky Karman, Seminar Kitab Hakim-hakim (Jakarta: YKBK, 2011), 4.

${ }^{4}$ M. P. Aritonang, Pengetahuan dan Pembimbing PL (Jakarta: SETIA Jakarta, 2007), 76.
} 
membebaskan bangsa Israel dari perbudakan musuh-musuh mereka, melainkan sekaligus mengajar atau mendisiplinkan mereka supaya kembali lagi kepada Tuhan.

Menurut Brian J. Bailey, "Tuhan mendisiplin bangsa Israel dengan cara Allah memberitahukan bangsa Israel bahwa Ia tidak akan memberi mereka kemenangan yang sepenuhnya atas musuh-musuh mereka karena bangsa Israel telah begitu lama tidak taat atau melakukan kesalahan di mata Tuhan." ${ }^{5}$ Bailey memberikan titik terang dari beberapa pandangan sebelumnya. Satu hal yang ditekankan oleh Bailey, bahwa dengan diizinkannya bangsa-bangsa kafir menindas atau menjajah bangsa Israel, maka hal itu sebenarnya bertujuan untuk mendisiplinkan mereka supaya bangsa Israel kembali kepada Allah yang dengan setia menjaga dan menolong mereka sejak exodus dari Mesir.

\section{B. Allah Mengajar dengan Kasih Sayang}

Brian menyatakan, 'selama periode Hakim-hakim, Tuhan mengajar bangsa Israel untuk mengetahui apa yang ada di dalam hati mereka setelah mereka tinggal di Tanah Perjanjian. ${ }^{6}$ Jelas bahwa umat Allah (bangsa Israel), dapat melewati periode-periode yang sulit di dalam kehidupan setelah berada di Tanah Perjanjian. Kadang-kadang Allah menarik diri untuk melihat apa yang akan dilakukan oleh umat-Nya. Allah tetap memberikan kebebasan kepada bangsa Israel untuk melakukan segala sesuatu seturut dengan yang mereka kehendaki. Namun, Tuhan akan meminta pertanggung jawaban dari mereka. Hal ini dapat dilihat juga di dalam kehidupan Raja Hizkia. Di dalam 2 Tawarikh 32:31 dikatakan bahwa, Tuhan menarik diri dari Hizkia selama sementara waktu untuk mengajar atau menguji, akan tetapi Hizkia yang adalah seorang yang saleh. Akhirnya dapat dilihat ending dari cerita tersebut bahwa akhirnya Raja Hizkia gagal dalam ujian ini, sebagaimana dicatat dalam (ay. 25), sehingga setelah dia berubah menjadi sombong, maka Allah akhirnya menghajarnya, supaya Hizkia dapat merendahkan hatinya di hadapan Tuhan.

Bertolak dari contoh yang dialami oleh raja Hizkia ini, maka dapat dilihat bahwa Allah menghukum bangsa Israel bukan karena Allah membenci mereka. Sebaliknya, Allah mengasihi bangsa Israel, dan ingin supaya bangsa Israel merendahkan diri dan mengandalkan Dia dalam kehidupan mereka. Allah perlu mengajar mereka; mengajar dengan penuh kasih sayang. Hal ini tampak dari banyaknya hakim (ada 13 hakim) yang Allah utus untuk mempertobatkan bangsa Israel. Karena Allah sangat mengasihi bangsa Israel, maka Allah tidak ingin bangsa Israel terus-menerus hidup dalam dosa.

Menurut Dianne Bergant, Tuhan tampaknya lebih tergerak hati-Nya oleh penderitaan bangsa Israel dari pada penyesalan mereka'. ${ }^{7}$ Apa yang dikemukakan Bergant di atas berpotensi multi-tafsir, karena ungkapannya sulit untuk dipahami dengan gamblang. Namun setelah menganalisis dengan serius dan hati-hati, maka dapat dilihat satu konsep pengajaran Alkitab yang terkandung dalam pernyataan tersebut. Sebenarnya Bergant hendak menegaskan bahwa Tuhan mengetahui benar sifat dari umat Israel. Umat Israel adalah umat yang tegar tengkuk. Umat yang selalu bersungutsungut, bahkan keras kepala, sehingga sulit bagi umat ini akan bertobat apabila tidak mengalami penderitaan terlebih dahulu. Tuhan akan lebih senang melihat mereka menderita karena dari situ akan muncul sebuah pertobatan dari mereka (bangsa Israel). Akan tetapi dalam hal ini, bukan berarti Allah tidak mengasihi mereka. Karena dari proses yang dialami oleh bangsa Israel, Allah mendidik mereka dengan kasih sayang.

\footnotetext{
5 Brian J. Bailey, Menuju Kemuliaan (Jakarta: Voice of Hope, 2004), 264.

6 Bailey, Menuju Kemuliaan, 262.

7 Dianne Bergant dkk., Tafsir Alkitab Perjanjian Lama (Yokyakarta: Kanisius, 2002), 255.
} 


\section{Yosia Belo}

Berangkat dari hal di atas, sangat jelas bahwa Allah mengasihi dan menyayangi umat-Nya; Ia mengajar mereka dengan kasih dan kepedulian-Nya. Selain itu, prinsip penting adalah: Allah itu "Maha Pengasih dan Maha Penyayang". Allah yang mendidik bangsa Israel pada zaman hakim, adalah Pribadi yang senantiasa penuh kasih dan sayang Allah kepada umat-Nya, agar mereka dapat melihat bahwa Dia layak disembah dan dipuji selamanya.

\section{Allah Peduli kepada Bangsa Israel yang Berdosa kepada-Nya}

Dennis Green dalam bukunya berjudul Pengenalan Perjanjian Lama menjelaskan bahwa, "dosa harus dihukum oleh Tuhan, baik yang dilakukan oleh orang besar (pemimpin misalnya Gidion [8:26-27; 34-35;9:4-5]; Simson [16:17-21]), maupun yang dilakukan oleh orang biasa $(2: 13-14 ; 3: 12 ; 4: 1-2)$ ". ${ }^{8}$ Dalam hal ini Green menjelaskan bahwa kekudusan Tuhan juga kelihatan, di mana Dia memakai bangsa-bangsa lain sebagai alatnya untuk menghukum umat Israel. Tetapi penghukuman itu terutama dimaksudkan bukan sebagai hukuman saja, melainkan sebagai didikan untuk mengembalikan orang Israel kepada jalan yang benar. Atau dengan perkataan lain bahwa Allah sangat peduli kepada dosa yang dilakukan oleh bangsa Israel (pasal 2:2022; 3:1-4). Kepeduliaan Allah terhadap dosa yang dilakukan oleh umat Israel tidak terlepas dari kasih-Nya kepada mereka (seperti yang dibahas sebelumnya). Bahwa karena Allah telah memilih bangsa Israel menjadi umat-Nya, sehingga Dia tidak rela untuk membiarkan umat Israel terus-menerus hidup dalam dosa. Allah ingin supaya umat pilihan-Nya ini dapat menjadi wakil Allah di tengah-tengah dunia yang penuh dengan dosa, Allah ingin supaya umat-Nya dapat menjadi contoh dan teladan dalam menegakkan kemuliaan-Nya di bumi, dan Allah juga ingin supaya melalui bangsa Israel akan muncul seorang juruselamat yang nantinya akan membebaskan umat manusia dari dosa (sebuah pengharapan Mesianik).

Penjelasan di atas menegaskan bahwa Allah sangat peduli dengan bangsa Israel meski mereka telah berdosa di hadapan-Nya. Bangsa Israel adalah bangsa yang dikhususkan bagi Allah. Mereka dituntut Allah untuk tetap mencerminkan kemuliaan Allah, sehingga ketika mereka melakukan dosa, pasti mereka akan diberikan hukuman oleh Allah.

Allah memiliki sifat murah hati dan sabar terhadap umat-Nya meski mereka sering berbuat salah dan dosa kepada-Nya. Asal mereka bertobat dan berseru kepada-Nya, maka Dia akan bersedia menerima mereka kembali, dan melepaskan mereka dari akibat-akibat dosa $(2: 16 ; 18 ; 3: 9,15)$. Dalam kedaulatan-Nya, Allah seringkali bertindak dengan cara yang tidak dapat dimengerti oleh manusia, dan sangat berbeda dengan cara manusiawi (misalnya: ketika Gidion mengalahkan orang Midian dengan 300 prajurit saja; [psl. 7] daya-daya alamiah diaturnya untuk menolong orang Israel [5:20-22]). Dalam peristiwa tersebut, Allah sebenarnya ingin menunjukkan kepada umat Israel bahwa ketika mereka berdosa maka pasti akan ada konsekuensi dari Allah sebagai tanda kepedulian-Nya kepada mereka. Namun, apabila mereka bertindak baik maka Tuhan akan membebaskan mereka dengan kuasa-Nya yang dahsyat.

Penjelasan-penjelasan di atas, hendak mengajarkan bahwa Allah menyatakan kasih dan kuasa-Nya untuk mengajar bangsa Israel, mengampuni mereka ketika mereka berseru dan bertobat dari dosa-dosa mereka. Dalam konteks Hakim-Hakim juga, Tuhan tetap menyatakan kasih-Nya, bahkan penghukuman-Nya kepada mereka yang berbuat dosa di hadapan-Nya. Hukuman Allah menjadi "pelaran" dan "didikan" bahwa Allah membenci dosa dan membenci para pelaku dosa. Di antara Hakim-hakim itu, terdapat beberapa orang yang jauh dari sempurna, misalnya: Ehud, yang membunuh dengan cara

\footnotetext{
8 Denis Green, Pengenalan Perjanjian Lama (Malang: Gandum Mas, 1984), 84.
} 
muslihat, dan Simson, yang memiliki moral yang tidak baik. Firman Tuhan tidak memuji hal-hal semacam ini atau membenarkan orang yang melakukannya. Akan tetapi Allah memilih serta memakai mereka, oleh karena mereka adalah orang yang benar-benar ingin dipakai oleh Tuhan, meskipun tokoh-tokoh tersebut tidak luput dari kelemahan, kekurangan, dan dosa. Jadi, meskipun dalam hal ini Allah menggunakan orang-orang yang berdosa, dengan tujuan menegur, menasihati, dan memperbaiki kerohanian mereka, namun mereka tidak bekerja sendiri, karena di balik usaha mereka, ada kuasa Allah yang senantiasa bekerja untuk membuat mereka bertobat. Hanya Allah yang sanggup dan mampu untuk membebaskan manusia dari perbudakan dosa; manusia hanya sebatas instrumenti di tangan-Nya.

Karena bangsa Israel meninggalkan Allah, Allah membiarkan mereka mengalami penderitaan di bawah penjajahan bangsa Midian (Hak. 6:7-10). Berdasarkan sudut pandang Allah, bisa dikatakan bahwa kemelaratan dan ketakutan yang dialami oleh bangsa Israel itu, merupakan anugerah Allah untuk mengingatkan umat-Nya agar mereka menyadari dosa-dosa mereka dan kembali kepada-Nya. Oleh karena tanpa penderitaan dan kesulitan, bangsa Israel akan merasa nyaman dan sulit untuk menyadari dosa mereka dan kembali kepada Allah. ${ }^{9}$ Hanya lewat penderitaan saja membuat mereka untuk dapat bertobat.

Di zaman hakim-hakim, bangsa Israel sangat jahat dan selalu berbuat dosa kepada Allah. Untuk mengatasi masalah ini, Allah menggunakan penderitaan dengan tujuan menyadarkan orang Israel. Ini terbukti dalam zaman hakim-hakim. Mereka menyadari bahwa hanya Tuhan yang dapat menolong mereka; Tuhanlah satu-satunya tempat untuk mencari pertolongan. Meskipun bangsa Israel telah berbuat dosa, Tuhan tetap dekat dengan mereka. Di saat bangsa Israel menjerit, Tuhan tetap setia mendengar dan memberi jawaban kepada umat-Nya. Allah berjanji bahwa Dia tidak akan meninggalkan atau mengabaikan mereka. Dengan demikian, dari elaborasi di atas, tampak bahwa Allah sangat peduli bangsa Israel meski mereka telah berbuat dosa terhadap Allah.

Dosa memang begitu berkuasa atas kehidupan bangsa Israel (bdk. Rm. 3:23). Akibatnya, mereka tidak dapat lagi memahami atau mengerti apa yang Allah kehendaki dalam hidup mereka. Bangsa Israel tidak lagi mampu memahami dan mengerti wahyu atau petunjuk Allah dalam hidup mereka. Allah telah membangkitkan para hakim, para nabi, dan raja-raja untuk memperkuat penyampaian pesan Allah kepada mereka. Akan tetapi mereka sudah tidak bisa lagi menangkap inti berita yang Allah sampaikan; mereka mengeraskan hatin, mereka mengandalkan kekuatan mereka sendiri. Tuhan peduli; Tuhan mengasihi mereka; Tuhan mengampuni mereka.

\section{Allah dengan Kesabaran Menanti Bangsa Israel Bertobat}

David L. Baker menyatakan, "oleh karena bangsa Israel tidak setia lagi kepada Allah, maka mereka ditindas oleh musuh dari luar dan timbullah kejahatan dalam masyarakat mereka sendiri. Namun pada zaman yang demikian pun Allah senantisa barsedia menolong umat-Nya, apabila mereka bertobat dari dosa- dosa mereka dan kembali kepada-Nya." 10 Pernyataan Baker di atas, sebenarnya hendak menegaskan bahwa tujuan Allah menghukum bangsa Israel dalam zaman hakim-hakim adalah supaya mereka sadar bahwa mereka sudah berbuat salah. Allah mengajar dan mendidik Israel dengan kasih yang luar biasa, dengan kesabaran-Nya.

Dalam kitab Hakim-hakim dijelaskan tentang circle sin bangsa Israel, yakni: (1) bangsa Israel melakukan kejahatan di mata Tuhan - mereka tidak lagi taat kepada

\footnotetext{
${ }^{9}$ http: //www.gpib-bukit moria.org/topik2.html.

10 David L. Baker, Mari Mengenal Perjanjian Lama (Jakarta: BPK Gunung Mulia, 2001), 60.
} 


\section{Yosia Belo}

firman-Nya dan jatuh dalam penyembahan berhala (berzinah dengan dewa-dewa orang Kanaan); (2) Tuhan murka - sehingga Ia membangkitkan musuh bagi orang Israel yaitu: bangsa-bangsa kafir yang ada di sekitar mereka dan bangsa Israel takluk dan dijajah oleh bangsa kafir itu; (3) ketika bangsa Israel sudah merasa menderita - mereka pun akhirnya ingat kepada Tuhan serta berseru-seru meminta pertolongan; (4) karena Allah sangat mengasihi mereka, maka Ia akhirnya mendengar seruan mereka - dengan membangkitkan hakim-hakim untuk membebaskan mereka dari penjajahan bangsa kafir dan memimpin mereka kepada Tuhan; (5) Akhirnya bangsa Israel merasakan kebebasan atau kemerdekaan selama puluhan tahun; (6) namun di saat mereka sudah terlalu nikmat dan enak - akhirnya mereka lupa lagi kepada Tuhan mereka dan berbuat dosa lagi. Hal inilah yang penulis maksudkan dengan circle sin (lingkaran dosa) bangsa Israel dalam zaman hakim-hakim.

Penjelasan tentang circle sin di atas dapat digambarkan sebagai berikut:

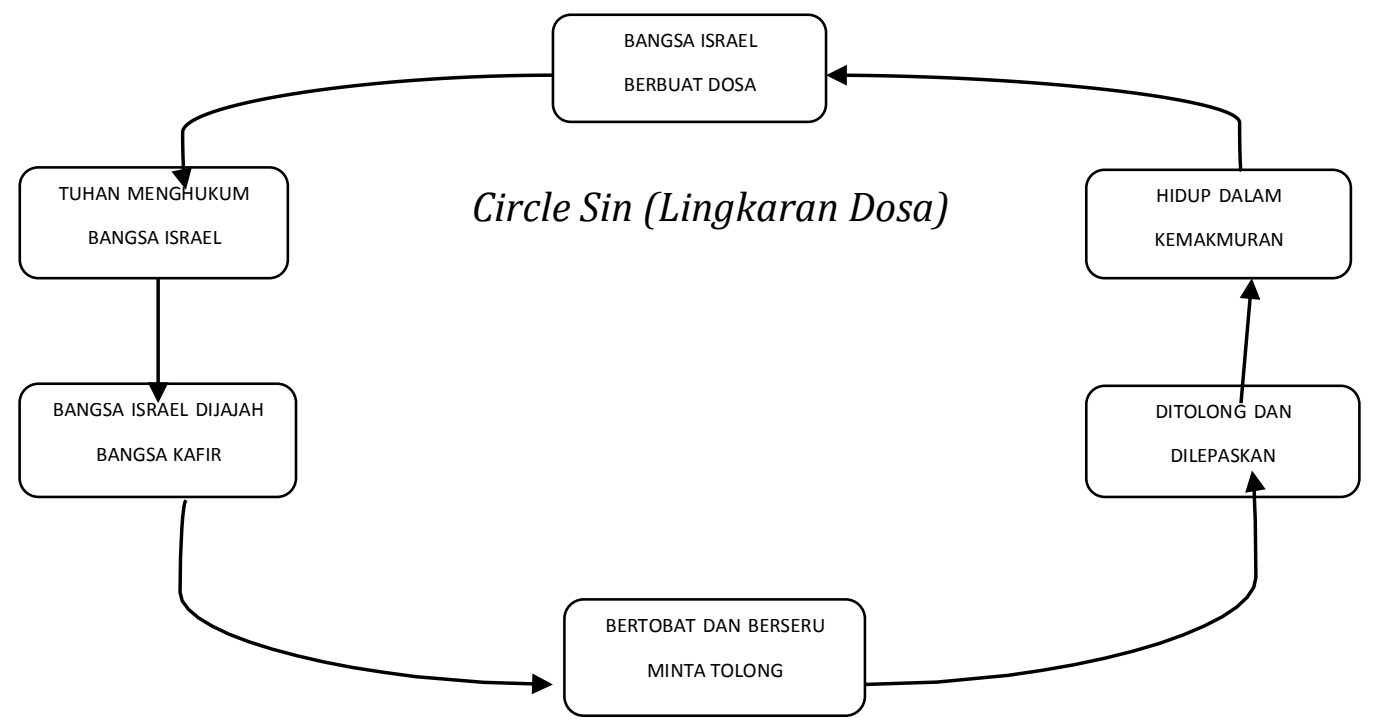

Dikatakan lingkaran dosa, karena seolah-olah dosa yang dilakukan oleh bangsa Israel pada zaman Hakim-Hakim tidak memiliki ujung - selalu berkesinambungan. Tanda panah menandakan bahwa ke arah itulah siklus dosa orang Israel.

Gambar circle sin di atas, menggambarkan kebobrokan bangsa Israel yang seolaholah hanya mempermainkan Allah. Apabila mereka merasa sejahtera, maka pasti mereka akan melupakan Allah. Sebaliknya, di saat menderita, baru mereka ingat kepada Allah. Kitab Hakim-hakim pun dideskripsikan dengan jelas bahwa perbuatan dosa bangsa Israel terpola atau memiliki susunan yang tersistem serta continue. Mereka berulang-ulang melanggar dan melupakan Tuhan.

Dengan memperhatikan kondisi seperti ini, maka tidak salah apabila dikatakan bahwa Allah sangat sabar dalam menantikan pertobatan orang Israel. Dengan panjang sabar, Allah menantikan bangsa Israel untuk kembali kepada-Nya. Inilah sifat Allah sesungguhnya; Ia memberikan kasih karunia yang melimpah kepada umat-Nya.

\section{E. Allah Mengajar dengan Pengampunan}

Menurut John Balchin, pelajaran penting yang dapat dilihat dari kitab Hakim-Hakim ialah Allah selalu dan dengan tanpa syarat siap untuk mengampuni dan menyelamatkan orang yang bertobat. ${ }^{11}$ Pernyataan Balchim, memberi kesan bahwa ada pelajaran

${ }^{11}$ John Balchin dkk., Intisari Alkitab Perjanjian Lama (Jakarta: Persekutuan Pembaca Alkitab, 2008), 59. 
penting mengenai cara Allah mengajar dan mendidik Israel; Allah yang mengajar dengan penuh pengampunan. 'Mengampuni' berarti 'tidak dendam'.

Apabila membaca kitab ini dengan teliti, ditemukan bahwa bangsa Israel kerap kali menyakiti hati Allah. Bangsa Israel melanggar titah-Nya, melakukan kejahatan, berzinah, kawin campur, menyembah dewa-dewa orang Kanaan, dan lain sebagainya. Semua tindak-tanduk orang Israel condong kepada dosa. Apa yang dilakukan bangsa Israel tidak sesuai dengan yang Allah kehendaki. Tentu hati Allah tersakiti. Tetapi kasih dan sayang Allah begitu melimpah. Allah tetap mengampuni mereka; pintu pengampunan selalu terbuka lebar bagi mereka; pengampunan yang sejati hanya bersumber dari Allah. Allah juga mau supaya "pengampunan" - sebagaimana yang Ia nyatakan kepada Israel, perlu juga diaktualisasikan dalam kehidupan umat-Nya.

Balchim berpendapat, Israel mengakui kesalahan mereka dan berbalik kepada Allah, memohon pengampunan, setiap kali Allah selalu bersedia mengampuni dan memulihkan mereka'.12 Apabila bangsa Israel mengakui kesalahan atau dosa mereka, maka Allah tetap bersedia mengampuni dan memulihkan mereka karena Ia sangat mengasihi mereka. Namun dalam hal ini, meskipun Allah selalu bersedia untuk mengampuni, namun dibutuhkan pula sebuah kerendah-hatian dari orang Israel untuk datang kepada Tuhan memohon ampun, dan mau merelakan hati untuk melakukan yang memuliakan Allah - meninggalkan segala perbuatan yang jahat.

Jadi, dalam konteks ini, ada dua hal yang tidak bisa dipisahkan, karena sifatnya berjalan bersama-sama, yaitu: (1) Allah selalu bersedia untuk mengampuni umat-Nya; namun juga diperlukan (2) kerelaan atau kemauan dari orang Israel untuk datang dan bertobat meninggalkan dosanya - hidup baru dalam Allah. Kedua hal ini tampak dengan jelas dalam teologi kitab Hakim-Hakim. Dengan demikian, cara Allah mendidik adalah tanpa emosi yang berlebihan, tanpa arogan, dan tanpa dendam, mendidik dengan pengampunan yang besar. Allah adalah Pendidik yang sejati.

\section{F. Allah Memberikan Ujian}

Seorang pendidik yang ingin mengetahui 'berhasil-tidaknya' proses mengajar, maka perlu untuk mengadakan tes (ujian) sebagai bahan evaluasinya. Hal ini yang sangat kental ditemukan dalam kitab Hakim-hakim. Jauh sebelumnya Allah sudah memberikan Hukum Taurat kepada bangsa Israel melalui Musa. Ketika bangsa Israel masih dalam perjalanan dari Mesir menuju Kanaan, di Padang Gurun tepatnya di gunung Sinai, Allah memberikan sepuluh perintah sebagai pedoman mereka.

Dalam Ulangan 6: 7-9 dijelaskan bahwa,

haruslah engkau mengajarkannya berulang-ulang kepada anak-anakmu dan membicarakannya apabila engkau duduk di rumahmu, apabila engkau sedang dalam perjalanan, apabila engkau berbaring dan apabila engkau bangun. Haruslah juga engkau mengikatkannya sebagai tanda pada tanganmu dan haruslah itu menjadi lambang di dahimu, dan haruslah engkau menuliskannya pada tiang pintu rumahmu dan pada pintu gerbangmu'.

Ayat ini ingin menegaskan satu hal bahwa orang Israel yang hidup pada zaman Hakimhakim sudah melalui proses belajar ini; Tuhan harus menguji mereka, sejauh mana mereka tahu, paham atau mengerti tentang Taurat Tuhan.

Berbicara tentang ujian, perlu dibedakan dari pencobaan. Ujian sifatnya positif, karena outputnya untuk menaikkan tingkatan hidup manusia. Ujian pasti selalu bersumber dari oknum-oknum yang baik (misalnya: Tuhan), sedangkan pencobaan

12 Balchin, Intisari Alkitab Perjanjian Lama, 55. 


\section{Yosia Belo}

sifatnya negatif, karena tujuannya supaya manusia itu jatuh (dilihat dari motifnya). Pencobaan pasti selalu bersumber dari oknum-oknum yang jahat (misalnya: Setan / Iblis). Dalam konteks Hakim-Hakim, Tuhan memberikan ujian kepada bangsa Israel sebagai bahan evaluasi, yang bertujuan untuk menaikkan tingkatan kerohanian umat Israel. Meskipun akhirnya dilihat bahwa ternyata bangsa Israel gagal dalam ujian ini.

Menurut Lasor, Hubbart, dan Bush, "masalah pokok yang dialami oleh bangsa Israel pada zaman Hakim-Hakim adalah mereka meninggalkan Allah dan berpaling kepada ilah-ilah Kanaan".13 Ada hal yang bertolak belakang dengan apa yang dikemukakan Musa dalam Ulangan 6: 7-9. Orang Israel yang seharusnya taat kepada Tuhan (melalui hukum Taurat), akan tetapi fakta berbicara lain, di mana mereka ternyata tidak setia kepada Allah mereka dan menyembah allah-allah yang mati.

Sejatinya, sudah lama Allah memerintahkan kepada bangsa Israel supaya orangorang Kanaan ditumpas habis (tidak ada seorang pun yang dibiarkan hidup). Perintah ini terkenal dengan 'Perjanjian di Bokhim', di mana Allah datang dan memerintahkan supaya, 'janganlah kamu mengikat perjanjian dengan penduduk negeri ini, mezbah mereka haruslah kamu robohkan' (Hak. 2:2). Namun sangat disayangkan, orang Israel gagal, dan akhirnya melanggar perintah Allah itu. Pasal-pasal awal dalam kitab Hakimhakim mengingatkan orang Kristen bahwa masih banyak kota yang belum direbut atau ditaklukkan. Bahkan mezbah-mezbah untuk menyembah berhala masih dibiarkan tegak berdiri, sehingga kondisi ini dipergunakan oleh Tuhan untuk menguji mereka (bangsa Israel).

Dalam Hakim-Hakim 2:3, dikatakan, 'Aku tidak akan menghalau orang-orang itu dari depanmu'. Ini adalah perkataan Tuhan kepada orang Israel. Oleh karena bangsa Israel tidak taat kepada kepada perintah Tuhan, maka Ia menggunakan kesalahan mereka untuk menguji mereka sendiri, sehingga apabila membaca pasal 3:1, maka di situ tampak dengan jelas bangsa-bangsa yang tidak ditumpas habis oleh orang Israel, akhirnya dipakai oleh Tuhan untuk menguji sejauh mana orang Israel taat kepada Tuhan. Dengan perkataan lain, ketidaktaatan orang Israel dipakai oleh Allah menjadi sarana untuk mengajar mereka, sehingga lebih memahami tujuan Allah dalam memilih mereka dan mengadakan hubungan yang istimewa dengan mereka.

Adapun tujuan dari ujian kepada orang Israel ini adalah untuk memperlihatkan kebenaran yang ganda, yakni: [1] Allah tetap setia memegang perjanjian-Nya, meskipun umat-Nya tidak setia, dan [2] apabila mereka (bangsa Israel) berseru kepada-Nya, maka pasti Tuhan akan menyelamatkan mereka. Itulah tujuan ujian dari Allah kepada umat Israel, supaya mereka mengerti bahwa tanpa Allah mereka tidak akan mampu untuk berbuat apa-apa. Selain itu, supaya mereka juga tahu bahwa meskipun mereka gagal menaati perjanjian yang mereka telah ikat dengan Allah, namun Allah tetap setia terhadap perjanjian itu. Hal ini juga tidak terlepas dari supaya orang Israel dapat meneladani kesetiaan Allah.

\section{G. Allah Memberikan Solusi}

Setelah memberikan ujian kepada umat Israel-dan Allah tahu bahwa ternyata mereka gagal dalam menjalankan ujian itu-maka tindakan mendidik Allah tidak terputus sampai di situ. Tindakan Allah menunjukkan bahwa Ia adalah Pendidik yang Agung: Allah memberikan solusi kepada bangsa Israel, membuktikan bahwa setelah ada evaluasi, maka Allah juga memberikan solusi supaya terjadi restorasi dalam bangsa Israel, sehingga mereka kembali kepada Allah.

Michael Wilcock menjelaskan, bahwa, "berkali-kali umat Allah atau bangsa Israel berpaling dari-Nya, sehingga Allah mengerahkan musuh terhadap mereka kemudian

\footnotetext{
13 Ibid., Lasor, 299.
} 
umat Allah atau bangsa Israel berseru mohon belas kasihan-Nya, dan Allah menanggapi dengan mengutus seorang penyelamat bagi mereka". ${ }^{14}$ Meskipun bangsa Israel, umat pilihan Allah melakukan kesalahan, yaitu berpaling dari Allah, Ia tetap menolong mereka dengan cara memberikan solusi, yakni: membangkitkan penyelamat atau seorang Hakim. I. Snoek menjelaskan, bahwa "bangsa Israel memberontak kepada Allah dan berbakti kepada berhala. Mereka dihukum, dan sesudah itu mereka berbalik pula kepada Tuhan. Lalu Tuhan memberikan seorang hakim untuk melepaskan bangsa Israel". ${ }^{15}$ Meskipun bangsa Israel berulang kali jatuh dalam dosa, namun dalam kesukaran mereka, ketika berseru kepada Allah, Allah menolong mereka dengan mengangkat seorang hakim untuk menyelamatkan mereka dari kesukaran itu. Meskipun hakim-hakim itu memiliki tabiat yang kasar, namun pembebasan yang diadakannya menjadi tanda ajaib yang bersumber dari Allah, selaku jawaban atas iman Israel kepadaNya. Dengan demikian, Israel pun mengenal Allah sebagai Pribadi yang benar, penuh kasih dan pengampunan.

Di awal telah dijelaskan bahwa: Allah mendidik bangsa Israel dengan cara mendisiplinkan, dengan kasih sayang, penuh kesabaran, pengampunan, dan memberikan ujian sebagai bahan evaluasi. Allah juga memberikan solusi. Ketika orang Israel berdosa, maka solusi yang Tuhan tawarkan adalah dengan membangkitkan hakim-hakim, untuk mengadili mereka. 'Pada umumnya mereka tidak melaksanakan peradilan, karena tugas utama mereka bukan untuk mendengar pengaduan atau membuat keputusan hukum. Akan tetapi, hakim-hakim dalam konteks ini adalah para pemimpin militer atau tokoh pembebas'16, sehingga dapat dilihat bahwa memang tujuan dibangkitkannya para hakim adalah untuk membebaskan umat Israel dari perbudakan bangsa kafir dan sekigus perbudakan dosa, dalam arti membebaskan bangsa Israel secara fisik dan juga secara rohani.

Solusi dari Allah adalah solusi yang efektif, meskipun dalam penerapannya seolaholah tidak. Hal ini disebabkan factor manusiawi yang terdapat dalam diri para hakim dan juga dalam diri orang Israel. Sehingga apabila diperhatikan dalam Kitab Hakimhakim, seringkali dijumpai justru para hakim juga ikut jatuh dalam dosa, contoh: Simson. Begitu juga pada pihak bangsa Israel, mereka seringkali lupa akan kemerdekaan yang Tuhan berikan kepada mereka, sehingga diperlukan tiga belas orang hakim untuk mendidik mereka. Akan tetapi tetap masih terdapat kekurangan-kekurangan. Cara Allah dalam mendidik orang Israel adalah cara yang memiliki tujuan untuk merestorasi bangsa Israel.

\section{Kesimpulan}

Berikut ini penulis merangkum ke tujuh cara Allah mendidik orang Israel. Pertama, Allah mendisiplinkan bangsa Israel ketika mereka bersalah. Zaman Hakim-Hakim adalah sejarah hitam bangsa Israel. Mereka banyak melakukan dosa dan menyakiti Allah. Sedangkan Allah sangat tidak senang terhadap dosa. Jadi, Allah perlu untuk mendisiplinkan orang Israel supaya mereka kembali kepada Allah.

Kedua, Allah mengajar bangsa Israel dengan kasih sayang. Ketika Allah mendisiplinkan bangsa Israel, Allah tidak menggunakan kekerasan. Akan tetapi Allah mendidik dengan penuh kasih sayang. Selain itu, ketika Allah mendidik mereka (bangsa Israel), itu karena Allah sangat mengasihi dan menyayangi mereka.

\footnotetext{
14 Michael Wilcock, Hakim-hakim (Jakarta: Yayasan Bina Kasih, 1996), 13.

15 I. Snoek, Sejarah Suci (Jakarta: BPK Gunung Mulia, 2010), 95.

16 Ibid., Lasor, 301.
} 


\section{Yosia Belo}

Ketiga, Allah peduli kepada dosa bangsa Israel. Allah Israel bukanlah Allah yang apatis terhadap dosa. Ketika Allah melihat bahwa bangsa Israel berbuat dosa, maka Allah peduli dengan sikap Allah yang mengajar dan mendisiplinkan mereka.

Keempat, Allah dengan kesabaran menantikan bangsa Israel bertobat. Allah tahu bahwa di saat bangsa Israel berbuat dosa, maka mereka perlu untuk diproses. Meskipun Allah bisa saja memakai cara yang instant. Akan tetapi Allah tetap dengan sabar memproses mereka kepada pertobatan sejati.

Kelima, Allah mengajar dengan pengampunan. Maksudnya, Allah tidak pernah dendam kepada bangsa Israel yang sudah seringkali menyakiti hati-Nya. Allah tetap mengampuni mereka.

Keenam, Allah memberikan ujian. Ujian penting sebagai bahan evaluasi. Ketika Allah mendidik orang Israel pada zaman Hakim-Hakim, Allah juga melakukan evaluasi. Dan evaluasi yang Allah pakai adalah dengan memakai bangsa-bangsa lain yang ada di sekitar mereka, sejauh mana mereka taat dan mengingat Taurat Tuhan.

Ketujuh, Allah memberikan solusi. Allah membuktikan bahwa untuk mendidik bangsa yang tegar tengkuk, harus dilakukan dengan tuntas. Tanpa adanya solusi dari Tuhan, maka pengajaran Tuhan dalam kitab Hakim-hakim tidak akan tuntas. Solusi dari Tuhan dengan membangkitkan hakim bagi mereka.

\section{Referenci}

Karman, Yonky. Seminar Kitab Hakim-hakim. Jakarta: YKBK, 2011. Aritonang, M. P. Pengetahuan dan Pembimbing PL. Jakarta: SETIA Jakarta, 2007.

Bailey, Brian J. Menuju Kemuliaan. Jakarta: Voice of Hope, 2004.

Bergant, Dianne, et al. Tafsir Alkitab Perjanjian Lama. Yokyakarta: Kanisius, 2002. Green, Denis. Pengenalan Perjanjian Lama. Malang: Gandum Mas, 1984.

http: //www.gpib-bukit moria.org/topik2.html.

Baker, David L. Mari Mengenal Perjanjian Lama. Jakarta: BPK Gunung Mulia, 2001.

Balchim, John, et al. Intisari Alkitab Perjanjian Lama. Jakarta: Persekutuan Pembaca Alkitab, 2008.

Wilcock, Michael. Hakim-Hakim. Jakarta: Yayasan Bina Kasih, 1996.

Snoek, I. Sejarah Suci. Jakarta: BPK Gunung Mulia, 2010. 